\title{
Comparative Composition of the Sheath of the Cyanobacterium Gloeothece ATCC 27152 Cultured with and without Combined Nitrogen
}

\author{
By BRUCE E. TEASE AND ROBERT W. WALKER* \\ University of Massachusetts, Environmental Science Program, Division of Public Health, \\ Morrill Science Center, Amherst, Massachusetts 01003-0081, USA
}

(Received 4 December 1986; revised 26 March 1987)

\begin{abstract}
The extracellular sheath was isolated from cultures of a unicellular diazotrophic cyanobacterium, Gloeothece ATCC 27152. Chemical analysis of lyophilized cell-free preparations indicated that the sheath was composed of an acidic heteropolysaccharide containing the neutral sugars rhamnose, 2-O-methylxylose, xylose, mannose, galactose and glucose, and the uronic acids mannuronic, glucuronic and galacturonic acid. Protein, pyruvic acid and $O$-acetyl and sulphate groups were also detected. Quantitative differences in the carbohydrate and protein content of the sheath were observed between material collected from cultures grown with and without a source of combined nitrogen. The extent to which the external layers bound cadmium ions was affected by these differences.
\end{abstract}

\section{INTRODUCTION}

The majority of cyanobacteria produce an external layer of polysaccharide, reminiscent of the glycocalyx and slime layers of bacteria. These extracellular investments occupy a strategic position at the outermost region of the bacterial cell envelope and thereby play a fundamental role in the interaction of cells with their environment (Cheng \& Costerton, 1975). Once in contact with a substrate, external layers help to anchor the cells and thereby permit further colonization by additional organisms (Daniels, 1980). Furthermore, bacterial external layers provide protection against phagocytic predation, antibody recognition, desiccation and lysis by bacteria and viruses (Dudman, 1977).

Bacterial external layers are composed of acidic polysaccharides containing an array of uronic acid and neutral sugar residues, frequently substituted with pyruvic acid and $O$-acetyl groups (Sandford, 1979; Troy, 1979; Sutherland, 1985). Sulphated and $O$-methyl sugars, common among eukaryotic extracellular polysaccharides (Percival, 1979; McCandles, 1981; Painter, 1983), have yet to be reported (Sutherland, 1985). Chemical analyses of the slime layers of certain cyanobacteria have revealed an array of uronic acid and neutral sugar residues similar to those found in bacterial external layers (Hough et al., 1952; Bishop et al., 1954; Moore \& Tischer, 1965; Dunn \& Wolk, 1970; Kokyrsta \& Chekoi, 1972; Sangar \& Dugan, 1972; Wang \& Tischer, 1973; Mehta \& Vaidya, 1978; Painter, 1983). The more structurally resilient sheaths of Chlorogloeopsis PCC 6912 (Schrader et al., 1982), Gloeothece PCC 6501 (Jurgens \& Weckesser, 1985) and Chroococcus minutus SAG B.41.79 (Adhikary et al., 1986) have been shown to contain $O$-methyl sugars and a protein component, in addition to the typical sugar residues detected in previously studied external layers.

The production of both bacterial and cyanobacterial external layers is affected by changes in culture conditions (Duguid \& Wilkinson, 1953; Wilkinson et al., 1954; Moore \& Tischer, 1964; Findley et al., 1970; Tischer \& Davis, 1971; Sangar \& Dugan, 1972; Fletcher \& Floodgate, 1973; Williams \& Wimpenny, 1978; Mehta \& Vaidya, 1978; Konopka \& Schnur, 1980). Increased production of extracellular polysaccharides appears to be directly proportional to the $\mathrm{C}: \mathrm{N}$ ratio. Changes in light intensity, temperature, culture age, and the concentrations of sulphur, 
phosphorus and potassium can also affect this production. Variations have been observed in the proportion of uronic acid residues in alginic acid (Haug et al., 1974) and in the extracellular polysaccharide of Pseudomonas atlantica (Uhlinger \& White, 1983). However, additional work is needed to determine the significance of such changes and the frequency with which they occur among external layers in general.

This paper describes the chemical characterization of the sheath of Gloeothece ATCC 27152 and the extent to which changes in the mode of nitrogen assimilation affect its composition.

\section{METHODS}

Growth conditions. Gloeothece ATCC 27152 (obtained from the American Type Culture Collection) is a member of section I of the generic classification scheme of Rippka et al. (1979). Cultures were grown photoautotrophically on medium BG-11 (Allen \& Stanier, 1968) with and without $\mathrm{NaNO}_{3}$, at $26^{\circ} \mathrm{C}$, in 15 litre glass carboys aerated with prefiltered compressed air. Illumination was continuously provided by two cool-white fluorescent lights $\left(3.4 \mathrm{~W} \mathrm{~m}^{-2}\right)$. Cultures were harvested after 1 month incubation, while in the exponential growth phase.

Sheath removal and isolation. Carboy cultures were allowed to settle to a density of $10^{7}$ cells $\mathrm{ml}^{-1}$. From a total cell concentrate of 1-2 litres per carboy, $30 \mathrm{ml}$ portions were transferred to a 2 litre porcelain jar containing 250 glass beads ( $3 \mathrm{~mm}$ in diameter) and revolved for $30 \mathrm{~min}$ at $4{ }^{\circ} \mathrm{C}$. This was repeated until all of the cell concentrate was milled. Sequential centrifugation for 5-10 min at 250,1000 and $38000 \mathrm{~g}$ separated liberated sheath from intact aggregates, sheathless cells and debris.

Lysozyme and SDS treatment. Since differential centrifugation was not totally effective in isolating pure sheath material, remaining cells were removed by treating the crude preparation with a $1 \%(w / v)$ solution of lysozyme (Sigma) for $20 \mathrm{~h}$ at $4^{\circ} \mathrm{C}$. After 10 rinses with deionized-distilled water, each followed by centrifugation at $38000 \mathrm{~g}$ for $10 \mathrm{~min}$, the sheath preparation was treated with a $3 \%(\mathrm{w} / \mathrm{v})$ aqueous solution of sodium dodecyl sulphate (SDS) for $1 \mathrm{~h}$ at room temperature. The resulting frothy suspension was centrifuged at $38000 \mathrm{~g}$ for $10 \mathrm{~min}$ and washed with deionized-distilled water 10 times. This material was transparent, colourless and virtually cell-free. Sheath material, before and after treatment with lysozyme and SDS, was lyophilized and stored at $-20^{\circ} \mathrm{C}$.

Analytical procedures. The water content of the final sheath preparation was determined by gravimetric analysis before and after dehydration at $95^{\circ} \mathrm{C}$ for $1 \mathrm{~h}$. The water loss observed was an indication of the amount of water absorbed by this material.

Phosphorus was determined after acid digestion of lyophilized sheath material in concentrated sulphuric and nitric acids, by the molybdenum blue assay according to Ma \& Rittner (1979).

Total lipid-soluble material was determined by extracting lyophilized sheath material for $3 \mathrm{~h}$ at room temperature in chloroform/methanol $(2: 1, \mathrm{v} / \mathrm{v})$, and weighing the dried extract. Sulphur was determined by combusting sheath material in a Schonizer oxygen flask, followed by the standard barium titration in ethanol, using thorin as the indicator reagent (Ma \& Rittner, 1979). Sulphate was determined by the turbidimetric-barium chloride procedure (American Public Health Association, 1980). Samples were hydrolysed in $0.5 \mathrm{M}$ - and $1.0 \mathrm{M}-\mathrm{HCl}$ for $\mathrm{I}$ and $28 \mathrm{~h}$ at $100^{\circ} \mathrm{C}$.

A modified ninhydrin procedure was followed to determine the protein content of the sheath material (Rosen, 1957). Samples were hydrolysed in $6 \mathrm{M}-\mathrm{HCl}$ at $100^{\circ} \mathrm{C}$ from $15 \mathrm{~min}$ to $24 \mathrm{~h}$. Amino acid analysis was performed on a model 121 Beckman amino acid analyser. Samples $(5 \mathrm{mg})$ were hydrolysed in $6 \mathrm{M}-\mathrm{HCl}$ for $20 \mathrm{~h}$ at $110^{\circ} \mathrm{C}$. After evaporation over $\mathrm{NaOH}$ in vacuo, $1 \mathrm{ml} 0.2 \mathrm{M}$-sodium citrate buffer $(\mathrm{pH} 2.2)$ was added. The amino acids were chromatographed at $55^{\circ} \mathrm{C}$ in a three-buffer system (pH 3.49, 4.20 and 6.40) using type $\mathrm{W}-1$ ion-exchange resin supported in a $56 \mathrm{~cm} \times 9 \mathrm{~mm}$ glass column. Colorimetric detection using ninhydrin was performed at $670 \mathrm{~nm}$ (except for proline, $440 \mathrm{~nm}$ ).

SDS-PAGE was performed according to Laemmli (1970) in the presence of $0.1 \%$ SDS using a discontinuous buffer system. Samples containing $5 \mathrm{mg}$ freeze-dried sheath preparation were suspended in $3 \%(\mathrm{w} / \mathrm{v}) \mathrm{SDS}, 0.5 \%$ Tris/ $\mathrm{HCl}$ buffer $\mathrm{pH} 6.8,10 \%(\mathrm{v} / \mathrm{v})$ glycerol and $5 \%(\mathrm{w} / \mathrm{v}) 2$-mercaptoethanol and heated for $3 \mathrm{~min}$ in a boiling water bath. Gel slabs $(0.75 \mathrm{~mm}$ thick), containing $3 \%(\mathrm{v} / \mathrm{v})$ (stacking gel) and $10 \%(\mathrm{v} / \mathrm{v})$ (running gel) acrylamide were placed in a Hoeffer SE-600 vertical slab gel unit that received a constant current of $15 \mathrm{~mA}$ and kept at $10-15^{\circ} \mathrm{C}$.

Total carbohydrate, uronic acid, pyruvic acid and $O$-acetyl groups were determined by the anthrone (Dreywood, 1946), $m$-phenylphenol (Blumenkrantz \& Asboe-Hansen, 1973), 2,4-dinitrophenylhydrazine (Lessie \& Whiteley, 1969) and hydroxylamine (Hestrin, 1949) colorimetric assays, respectively. The presence of hexosamines was measured by the Morgen-Elson procedure (Gerhardt, 1981). Neutral (Swardeker, 1965) and uronic acid (Lehrfeld, 1985) sugars were identified by gas-liquid chromatography of their alditol acetate and $N$-propylamide acetate derivatives, respectively. A Perkin-Elmer model 900 gas chromatograph with dual ionization detectors was used in a dual column compensation mode. Stainless steel columns $(168 \mathrm{~cm} \times 3 \mathrm{~mm})$ were packed with $80-100$ mesh Supelcoport (Supelco, Inc.), coated with $3 \%(w / w)$ OV-225. The temperature was programmed from 140 to $240{ }^{\circ} \mathrm{C}$ 
at $5^{\circ} \mathrm{C} \mathrm{min}-1$ and finally kept isothermal at $240^{\circ} \mathrm{C}$ until all components eluted. Nitrogen was used as the carrier gas at a rate of $55 \mathrm{ml} \mathrm{min}-1$. Acid hydrolysis of lyophilized sheath was performed with $2 \mathrm{M}$-trifluoroacetic acid (TFA) and $0.5 \mathrm{M}-\mathrm{H}_{2} \mathrm{SO}_{4}$ at $100^{\circ} \mathrm{C}$ from $15 \mathrm{~min}$ to $20 \mathrm{~h}$. (It should be noted that TFA interfered with $N$ propylamide acetate derivatization of uronic acid residues.) $\mathrm{H}_{2} \mathrm{SO}_{4}$ was neutralized with $\mathrm{BaCO}_{3}$, and TFA was evaporated over $\mathrm{NaOH}$ in vacuo. A $0.03 \%(\mathrm{w} / \mathrm{v})$ aqueous solution of arabinose was used as an internal standard. Gas chromatography-mass spectrometry was used to assist identification of neutral sugars. Electron impact and chemical ionization using isobutane was performed on a model HP 5985 Hewlett-Packard GC-mass spectrometer coupled by an open split interface.

Cadmium-binding studies. Lyophilized sheath preparations $(2.0 \mathrm{mg})$ were exposed to a range of cadmium (as cadmium nitrate) concentrations $\left(25,50,75,100,150\right.$ and $\left.200 \mu \mathrm{g} \mathrm{Cd}^{2+} \mathrm{ml}^{-1}\right)$. After $30 \mathrm{~min}$ the sheath/metal suspension was allowed to settle for $2 \mathrm{~h}$. Cadmium concentrations were determined on 1:25 dilutions of the supernatant and on standard solutions, using a Perkin-Elmer ICP (inductively-coupled plasma) model 6500 atomic emission spectrophotometer.

\section{RESULTS}

\section{Cultivation and sheath removal}

Differences in the growth rate of Gloeothece ATCC 27152 grown with $\mathrm{N}_{2}$ or with $\mathrm{NaNO}_{3}$ as nitrogen source were negligible. Average generation times for the cultures were approximately $4 \mathrm{~d}$. Accelerating the growth rate by providing additional inorganic carbon resulted in a diminished sheath/cell volume ratio. Sheath removal was best performed on aggregates containing 8-16 cells (Fig. 1).

Removal procedures were directed at the outermost sheath investment. Exposure of concentrated cell suspensions to ball milling for short periods fractured the external sheath, resulting in the dispersion of the enclosed cell clusters. While this may not have been the most productive method to obtain sheath material, it proved to be the best for minimizing cell breakage.

The outer sheath investment maintained a sack-like conformation (Fig. 2) throughout the removal procedures. Purification of this material involved separating the extended sacks of sheath from cell clusters, sheathless cells and debris (fragments of broken cells). Lysozyme and SDS were used to break down the remaining cells and debris not removed by centrifugation. Isolated sheath material was considered to be homogeneous based upon the absence of whole cells and upon its low phosphorus $(0.06 \%)$ and lipid $(0.3-0.5 \%)$ content, suggesting negligible membrane contamination.

Approximately $150 \mathrm{mg}$ lyophilized sheath material could be collected from an exponentially growing carboy culture (15 litres).

\section{Chemical analyses}

In general, the sheath of Gloeothece ATCC 27152 contained the neutral sugars rhamnose, 2-Omethylxylose, xylose, mannose, galactose and glucose, and the uronic acids mannuronic, glucuronic and galacturonic acid (Fig. 3). Pyruvic acid, $O$-acetyl and sulphate groups were also detected; this is believed to be the first report of these groups in extracellular polysaccharide from cyanobacteria. While pyruvate and $O$-acetyl groups are common in bacterial polysaccharides, the occurrence of sulphates and methylated sugars is unique.

The results from the Morgen-Elson test for hexosamines were negative. This, however, should not be considered absolute. The limited supply of sheath material necessitated using small amounts for a test that depends upon larger quantities for precision. Further research regarding the presence of amino sugars in the sheath of Gloeothece ATCC 27152 is required.

Amino acid analysis revealed a wide variety of residues, suggesting the presence of complex proteins. The high proportion of aspartic acid and glycine detected (Table 1) was similar to results observed with the sheath of Chlorogloeopsis PCC 6912 (Schrader et al., 1982). SDSPAGE revealed two sharp major bands of $M_{\mathrm{r}} 56000$ and 51000 , a broad minor band of $M_{\mathrm{r}} 18000$ and a broad major band of $M_{\mathrm{r}} 14000$ (Fig. 4). 


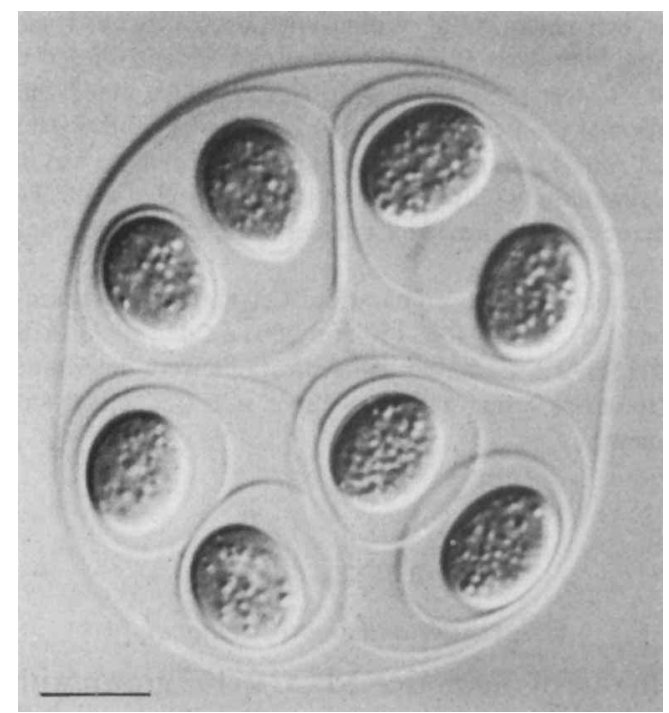

Fig. 1. Photograph of a cell aggregate of Gloeothece ATCC 27152 showing characteristic multilaminated sheath investments. Bar, $10 \mu \mathrm{m}$.

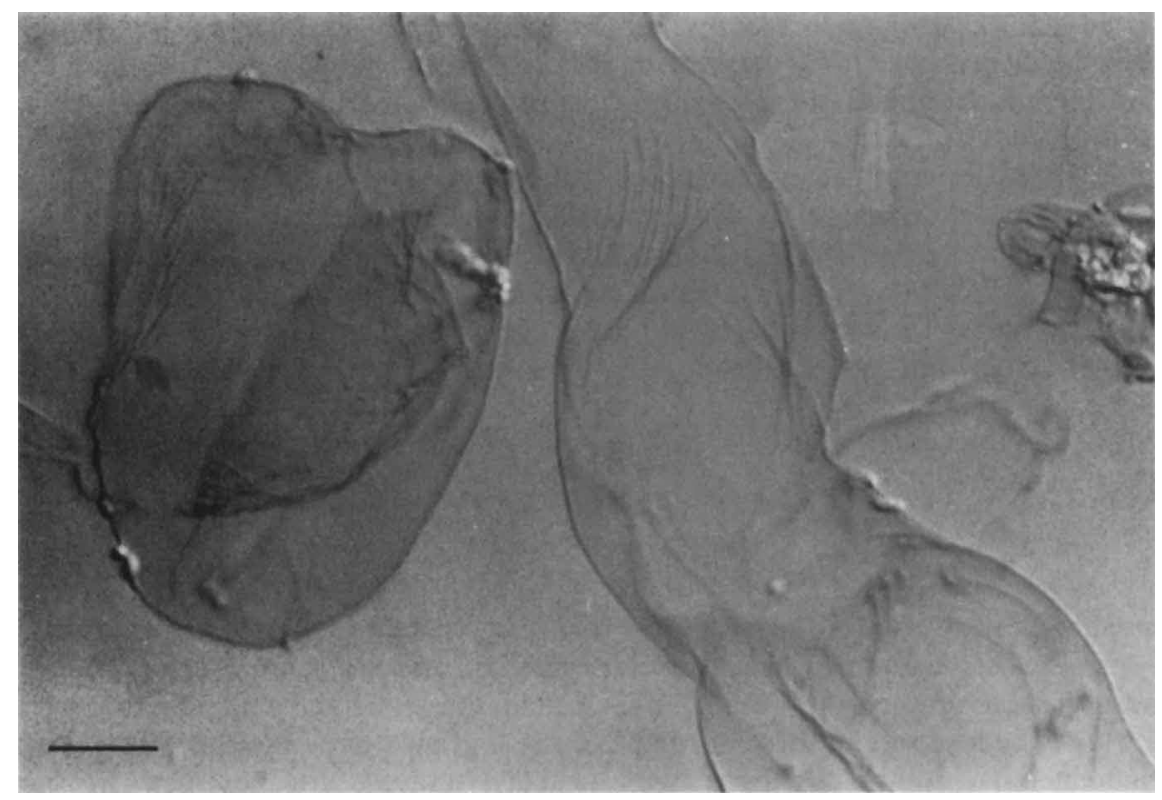

Fig. 2. Photograph of the sheath material after removal procedures. Bar, $10 \mu \mathrm{m}$.

Quantitative differences were observed in the composition of the sheath material collected from cultures grown with $\mathrm{NaNO}_{3}$ and from those fixing $\mathrm{N}_{2}$ (Table 2). When viewed under the light microscope, material from cultures grown with $\mathrm{N}_{2}$ was more refractile and voluminous than that from cultures grown with $\mathrm{NaNO}_{3}$, but it contained $26 \%$ and $42 \%$ less total carbohydrate and protein, respectively, than the latter material. The water content (prior to lyophilization) of sheath from cultures grown with $\mathrm{N}_{2}$ was $98.8 \%$, compared to $99.5 \%$ for sheath 

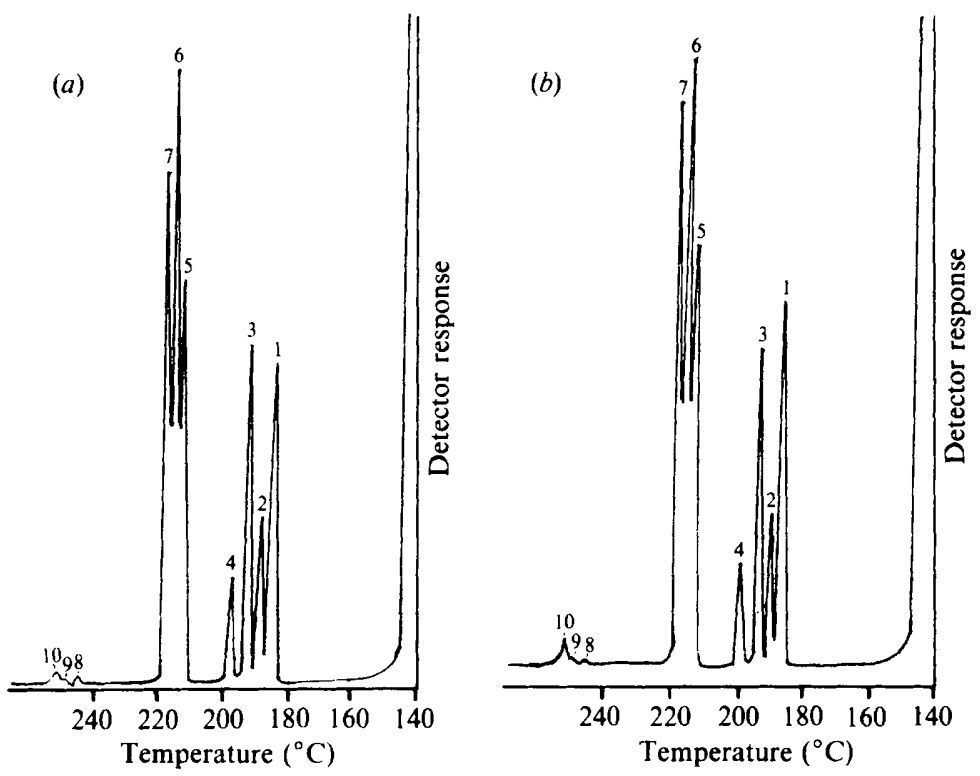

Fig. 3. FID (flame ionization detector) trace of the $N$-propylamide and alditol acetate derivatives of the uronic acid and neutral sugar residues from the sheath of Gloeothece ATCC 27152 grown $(a)$ with $\mathrm{NaNO}_{3}$ and $(b)$ with $\mathrm{N}_{2}$ as nitrogen source, analysed by gas chromatography. Peak numbers 1 to 10 refer to rhamnose, 2-O-methylxylose, arabinose, xylose, mannose, galactose, glucose, mannuronic acid, glucuronic acid and galacturonic acid, respectively.

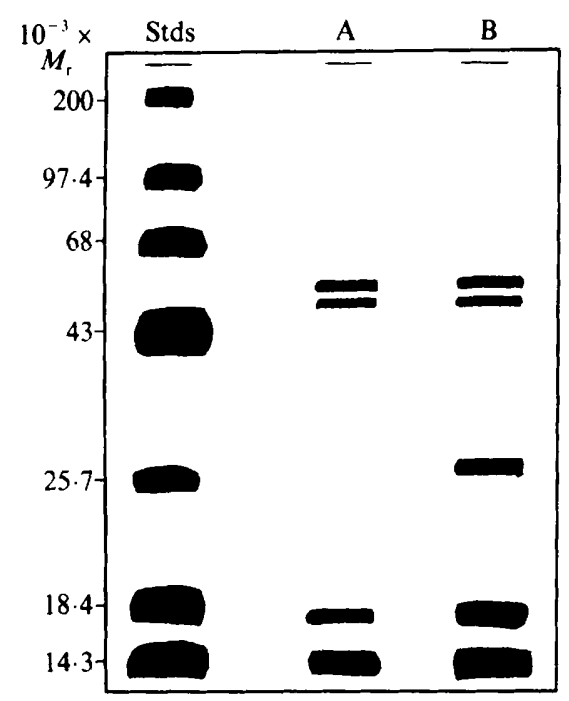

Fig. 4

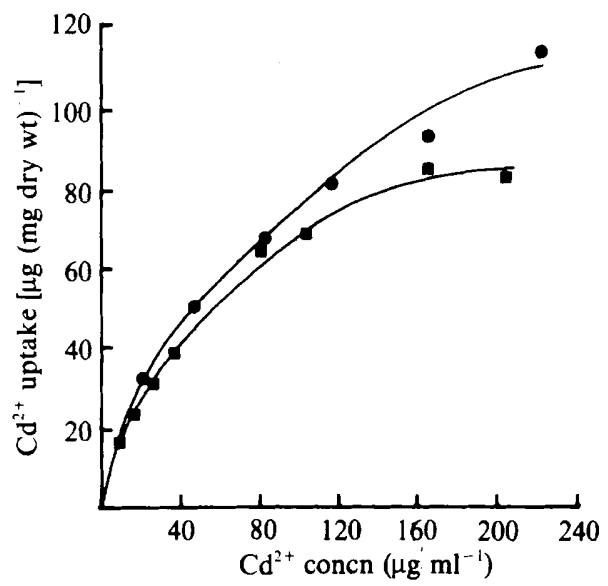

Fig. 5

Fig. 4. Line drawing of an SDS-PAGE gel showing the protein standards (Stds) and bands from two samples of sheath from cells grown with $\mathrm{N}_{2}$. A, $4.98 \mathrm{mg}$ material treated with lysozyme and SDS; B, $5.00 \mathrm{mg}$ material treated with SDS only. Both wells received $30 \mu 1$ sample extract.

Fig. 5. Adsorption of cadmium ions to the sheath of Gloeothece ATCC 27152 collected from cultures grown with $\mathrm{NaNO}_{3}(\mathrm{O})$ and with $\mathrm{N}_{2}(\square)$ as nitrogen source. Points represent single determinations. 
Table 1. Amino acid composition of the protein component in the sheath preparation from nitrate-grown Gloeothece ATCC 27152 after lysozyme/SDS treatment

Values represent a single analysis and are based upon a percentage of alanine.

$\begin{array}{cccc}\text { Amino acid } & \begin{array}{c}\text { Content } \\ (\mathrm{mol} \%)\end{array} & \text { Amino acid } & \begin{array}{c}\text { Content } \\ (\mathrm{mol} \%)\end{array} \\ \text { Asp } & 110 & \text { Met } & 9 \\ \text { Thr } & 56 & \text { Ile } & 50 \\ \text { Ser } & 83 & \text { Leu } & 78 \\ \text { Glu } & 79 & \text { Tyr } & 31 \\ \text { Pro } & 8 & \text { Phe } & 59 \\ \text { Cys } & 8 & \text { His } & 14 \\ \text { Gly } & 102 & \text { Lys } & 50 \\ \text { Ala } & 100 & \text { Arg } & 70 \\ \text { Val } & 62 & & \end{array}$

Table 2. Chemical composition ( $\%$ dry wt) of the sheath of Gloeothece ATCC 27152 collected from cultures assimilating nitrate or fixing $\mathrm{N}_{2}$

\begin{tabular}{|c|c|c|}
\hline Parameter & $\begin{array}{c}\mathrm{N}_{2} \text { as } \\
\text { nitrogen source }\end{array}$ & $\begin{array}{l}\mathrm{NO}_{3}^{-} \text {as } \\
\text { nitrogen source }\end{array}$ \\
\hline Total carbohydrate & $41 \cdot 0$ & $55 \cdot 4$ \\
\hline Total uronic acids & 7.6 & $6 \cdot 0$ \\
\hline \multicolumn{3}{|l|}{ Protein } \\
\hline $3 \mathrm{~h}$ hydrolysis & $4 \cdot 3$ & $7 \cdot 3$ \\
\hline 8 h hydrolysis* & $6 \cdot 3$ & $10 \cdot 9$ \\
\hline \multicolumn{3}{|l|}{ Water } \\
\hline Gel preparation & 99.8 & $99 \cdot 5$ \\
\hline Sheath preparation & $4 \cdot 3$ & $4 \cdot 3$ \\
\hline Total sulphur & $5 \cdot 3$ & $5 \cdot 2$ \\
\hline \multicolumn{3}{|l|}{ Sulphate } \\
\hline ith hydrolysis & $13 \cdot 2$ & 8.7 \\
\hline $28 \mathrm{~h}$ hydrolysis & $15 \cdot 4$ & $17 \cdot 5$ \\
\hline$O$-Acetyl & $2 \cdot 2$ & $3 \cdot 1$ \\
\hline Pyruvate† & $2 \cdot 3$ & ND \\
\hline
\end{tabular}

Table 3. Peak area and proportions (relative to xylose), determined by gas chromatography (Fig. 3), of the $\mathrm{N}$-propylamide and alditol acetate derivatives of the sugar residues from samples of sheath material from cultures assimilating nitrate or fixing $\mathrm{N}_{2}$

Samples were hydrolysed for $10 \mathrm{~h}$ at $100^{\circ} \mathrm{C}$ in $0.5 \mathrm{M}-\mathrm{H}_{2} \mathrm{SO}_{4}$. Arabinose served as internal standard ( $1.5 \mu \mathrm{g}$ per $0.5 \mu \mathrm{l}$ injection).

Peak
no.
1
2
3
4
5
6
7
8
9
10

\begin{tabular}{lcccr}
\multicolumn{1}{c}{ Component } & $\overbrace{\begin{array}{c}\text { Peak area } \\
\left(\mathrm{cm}^{2}\right)\end{array}}^{\mathrm{N}_{2} \text { as nitrogen source* }}$ & \multicolumn{2}{c}{$\begin{array}{c}\text { Peak area } \\
\left(\mathrm{cm}^{2}\right)\end{array}$} \\
Rhamnose & 1.11 & 3.50 & 0.96 & 3.00 \\
$2-O$-methylxylose & 0.46 & 1.50 & 0.51 & - \\
Arabinose & 0.96 & - & 1.01 & 1.00 \\
Xylose & 0.32 & 1.00 & 0.28 & 6.50 \\
Mannose & 1.91 & 6.00 & 1.83 & 10.00 \\
Galactose & 2.75 & 9.00 & 2.78 & 8.00 \\
Glucose & 2.55 & 8.00 & 2.31 & 0.14 \\
Mannuronic acid & 0.02 & 0.06 & 0.04 & 0.11 \\
Glucuronic acid & 0.03 & 0.09 & 0.03 & 0.40 \\
Galacturonic acid & 0.16 & 0.50 & 0.11 &
\end{tabular}


from cultures grown with $\mathrm{NaNO}_{3}$. While the proportion of neutral sugars was virtually the same in material from the two cultures, the uronic acid of sheath from $\mathrm{N}_{2}$-fixing cultures contained much less mannuronic acid (Table 3).

\section{Cadmium-binding ability}

Alterations in the chemical composition of the sheath of Gloeothece ATCC 27152 affected its capacity to bind cadmium ions: sheath material from cells grown with $\mathrm{NaNO}_{3}$ bound considerably more than that from $\mathrm{N}_{2}$-fixing cultures (Fig. 5).

\section{DISCUSSION}

The sheath of Gloeothece ATCC 27152 was primarily composed of an acidic heteropolysaccharide, substituted with several functional groups, representative of both eukaryotic and prokaryotic extracellular polysaccharides. The presence of protein, uronic acids, pyruvic acid and $O$-methyl, $O$-acetyl and sulphate groups indicates a significant degree of complexity. The presence of a variety of components in the sheath of Gloeothece ATCC 27152 may convey resistance to bacterial decomposition, since several enzymes may be needed to achieve complete breakdown of the heteropolysaccharide.

A possible function of external layers may be the concentration of essential trace elements, present at submarginal concentrations in oligotrophic environments (Lange, 1976; Geesey, 1982; Uhlinger \& White, 1983). The occurrence of several functional groups (carbonyl, carboxyl, hydroxyl and sulphate) would provide various attachment sites for cations (Eichorn, 1975), and thereby facilitate nutrient uptake into the cell. By concentrating certain nutrients at the cell surface, an organism could proliferate in an environment otherwise uninhabitable due to an insuffient nutrient supply. While cadmium is not an essential nutrient, its substantial adsorption to the sheath of Gloeothece ATCC 27152 indicates the appreciable metal-binding capacity of this extracellular investment. The variations in composition observed in the sheath material collected from cultures grown with and without a combined nitrogen source resulted in differences in metal-binding capacity. Future research should be directed at determining the extent to which changes in the metal-binding affinity of external layers are directed by the cells. It would be interesting to determine if a binding preference results during periods of rapid assimilation and/or limited nutrient supply (e.g. adsorption of iron and molybdenum during $\mathrm{N}_{2}$ fixation).

This work (paper no. 2813) has been funded by the Massachusetts Experimental Station, Hatch project 560. Special appreciation goes to Dr Thomas Potter, Dr Gregory Dabkowski, Dr Michael DeCheke, Dr Lloyd and Judy Semprivivo, Dr Morkatah Attalah and Irene Ellis for their assistance in the analytical portion of this research.

\section{REFERENCES}

Adhikary, S. P., WeckesSer, J., JURgens, U. J., GoleCKI, J. R. \& BOROWIAK, D. (1986). Isolation and chemical characterization of the sheath from the cyanobacterium Chroococcus minutus SAG B.41.79. Journal of General Microbiology 132, 25952599.

ALlen, M. M. \& Stanier, R. Y. (1968). Growth and division of some unicellular blue-green algae. Journal of General Microbiology 51, 199-202.

American Public Health Association (1980). Standard Methods for the Examination of Water and Wastewater, 15th edn. Washington, DC: American Public Health Association.

Bishop, C. T., Adams, G. A. \& Hughes, E. O. (1954).
A polysaccharide from the blue-green alga Anabaena cylindrica. Canadian Journal of Microbiology 11, 877885.

Blumenkrantz, N. \& Asboe-Hansen, G. (1973). New method for quantitative determination of uronic acids. Analytical Biochemistry 54, 484-489.

ChENG, K. J. \& COSTERTON, J. W. (1975). Ultrastructure of cell envelopes of bacteria of the bovine rumen. Applied Microbiology 29, 841-849.

DANIELS, S. S. L. (1980). Mechanisms involved in sorption of microorganisms to solid surfaces. In Adsorption of Microorganisms to Surfaces, pp. 7-58. Edited by G. Bitton \& K. C. Marshall. New York: Wiley-Interscience. 
DREYwOOD, R. (1946). Qualitative test for carbohydrate material. Industrial and Engineering Chemistry, Analytical Edition 18, 499.

DudMan, W. F. (1977). The role of surface polysaccharides in natural environments. In Surface Carbohydrates of the Procaryotic Cell, pp. 357-414. Edited by 1 . W. Sutherland. London: Academic Press.

Duguid, J. P. \& WILkinson, J. F. (1953). The influence of culture conditions on polysaccharide production by Aerobacter aerogenes. Journal of General Microbiology 9, 174-189.

DUnN, J. H. \& WolK, C. P. (1970). Composition of the cellular envelope of Anabaena cylindrica. Journal of Bacteriology 103, 153-158.

EICHHORN, G. L. (1975). Active sites of biological macromolecules and their interaction with heavy metals. In Ecological Toxicology Research, ch. 6. Edited by A. D. McIntyre \& C. F. Mills. New York: Plenum Press.

Findley, D. L., Walne, P. L. \& Holton, R. W. (1970). The effects of light intensity on the ultrastructure of Chlorogloeoa fritschii Mitra grown at high temperature. Journal of Phycology 6, 182-188.

Fletcher, M. \& Floodgate, G. D. (1973). An electron-microscopic demonstration of an acidic polysaccharide involved in the adhesion of a marine bacterium to solid surfaces. Journal of General Microbiology 74, 325-334.

GeEsey, G. G. (1982). Microbial exopolymers : ecological and economic considerations. $A S M$ News 48, 9 14.

GerhardT, P. (1981). Mamual of Methods for General Bacteriology, pp. 335-336. Washington, DC: ASM.

Haug, A., LARSEN, B. \& Smidsrod, O. (1974). Uronic acid sequence in alginate from different sources. Carbohydrate Research 32, 217-225.

HESTRIN, S. (1949). The reaction of acetylcholine and other carboxylic acid derivatives with hydroxylamine and its analytical application. Journal of Biological Chemistry 180, 249-261.

Hough, L., Jones, J. K. N. \& Wadman, W. L. T. (1952). An investigation of the polysaccharide components of certain freshwater algae. Journal of the Chemical Society 3393-3399.

JURGENS, U. J. \& WeCKesser, J. (1985). The fine structure and chemical composition of the cell wall and sheath layers of cyanobacteria. Annales de l'Institut Pasteur/Microbiologie 136A, 41-44.

Koxyrsta, P. N. \& CheKol, V. N. (1972). Biochemical composition of the blue-green alga Nostoc linckia $f$. muscorum (AG) Elenk. and its lifelong production. (In Russian). Seria Biologicheskaia Khimia 2, 46-48.

Konopka, A. \& SChNur, M. (1980). Effect of light intensity on macromolecular synthesis in cyanobacteria. Microbial Ecology 6, 291-301.

LAEMMLI, U. K. (1970). Cleavage of structural proteins during the assembly of the head of bacteriophage T4. Nature, London 227, 680-685.

LANGE, W. (1976). Speculations on a possible essential function of the gelatinous sheath of blue green algae. Canadian Journal of Microbiology 22, 1181-1185.

LEHRFELD, J. (1985). Simultaneous gas-liquid chromatographic determination of aldonic acids and aldoses. Analytical Chemistry 57, 346-348.

Lessie, T. G. \& Whiteley, H. R. (1969). Properties of threonine deaminase from a bacterium able to use threonine as sole source of carbon. Journal of Bacteriology 100, 878-889.

MA, T. S. \& RITTNER, R. C. (1979). Modern Organic Elemental Analysis. New York: Marcel Dekker

McCandles, E. L. (1981). The Biology of the Seaweeds (Botanical Monographs vol. 17). Edited by C. Lobban \& M. J. Wynne. Berkeley \& Los Angeles: University of California Press.

Mehta, V. B. \& VaIdYa, B. S. (1978). Cellular and extracellular polysaccharides of the blue green alga Nostoc. Journal of Experimental Botany 29, 1423 1430

MOORE, B. G. \& Tischer, R. G. (1964). Extracellular polysaccharides of algae: effects on life-support systems. Science $145,586$.

MOORE, B. G. \& TISCHER, R. G. (1965). Biosynthesis of extracellular polysaccharides by the blue green alga Anabaena flos-aquae. Canadian Journal of Microbiology 11, 877-885.

PAINTER, T. J. (1983). Algal polysaccharides. In The Polysaccharides, vol. 2, ch. 2. Edited by G. O. Aspinall. New York: Academic Press.

Percival, E. (1979). The polysaccharides of green, red and brown seaweeds: their basic structure, biosynthesis and function. British Phycological Journal 14, 103-117.

RipPKa, R., Deruelles, J., Waterbury, J. B., Herdman, M. \& Stanier, R. Y. (1979). Generic assignments, strain histories and properties of pure cultures of cyanobacteria. Journal of General Microbiology 111, 1-61.

Rosen, H. (1957). A modified ninhydrin colorimetric analysis for amino acids. Archives of Biochemistry and Biophysics 67, 10-15

SANDFORD, P. A. (1979). Exocellular microbial polysaccharides. Advances in Carbohydrate Chemistry and Biochemistry 36, 265-313.

SangaR, V. K. \& Dugan, P. R. (1972). Polysaccharide produced by Anacystis nidulans: its ecological implications. Applied Microbiology 24, 732-734.

Schrader, M., Drews, G., Golecki, J. R. \& WECKESSER, J. (1982). Isolation and characterization of the sheath from the cyanobacterium Chlorogloeopsis PCC 6912. Journal of General Microbiology 128, 267-272.

Sutherland, I. W. (1985). Biosynthesis and composition of gram-negative bacterial extracellular and wall polysaccharides. Annual Review of Microbiology 39, 243-270.

SWardeker, J. S., Sloneker, J. H. \& Jeanes, A. (1965). Quantitative determination of monosaccharides as their alditol acetates by gas-liquid chromatography. Analytical Chemistry 37, 1602-1604.

TISCher, R. G. \& Davis, E. B. (1971). The effect of various nitrogen sources upon the production of extracellular polysaccharide by the blue green alga Anabaena flos-aquae A37. Journal of Experimental Botany 22. 546-551

TroY, F. A. (1979). The chemistry and biosynthesis of selected bacterial capsular polymers. Annual Review of Microbiology 33, 519-560.

Uhlinger, D. J. \& White, D. C. (1983). Relationship between physiological status and formation of extracellular polysaccharide glycocalyx in Pseudomonas atlantica. Applied and Environmental Microbiology 45, 64-70. 
Wang, W. S. \& Tischer, R. G. (1973). Study of the extracellular polysaccharides produced by a blue green alga, Anabaena flos-aquae A37. Archives of Microbiology 91, 77-81.

Wilkinson, J. F., Duguid, J. P. \& Edmunds, P. N. (1954). The distribution of polysaccharide in Aerobacter and Escherichia strains and its relation to antigenic character. Journal of General Microbiology 11, 59-72.

Williams, A. G. \& WimpenNy, J. W. T. (1978). Exopolysaccharide production by Pseudomonas NCIB 11264 grown in continuous culture. Journal of General Microbiology 104, 47-57. 